\title{
Explore the Path of High-Quality Applied Undergraduate Talents under the Background of Ideological and Politics
}

\author{
Shuang Zhang, Wenqian Yang \\ Faculty of International Economics and Trade, Zhejiang Yuexiu University, Shaoxing, China \\ Email: 20182057@zyufl.edu.cn
}

How to cite this paper: Zhang, S., \& Yang, W. Q. (2021). Explore the Path of High-Quality Applied Undergraduate Talents under the Background of Ideological and Politics. Advances in Applied Sociology, 11, 530-539. https://doi.org/10.4236/aasoci.2021.1111047

Received: October 7, 2021

Accepted: November 21, 2021

Published: November 24, 2021

Copyright $\odot 2021$ by author(s) and Scientific Research Publishing Inc. This work is licensed under the Creative Commons Attribution International License (CC BY 4.0).

http://creativecommons.org/licenses/by/4.0/

\begin{abstract}
General Secretary Xi Jinping pointed out at the National Conference on Ideological and Political Work in Colleges and Universities, "We must make good use of the main channel of classroom teaching, and the ideological and political theory courses should be strengthened in improvement, and the affinity and pertinence of ideological and political education should be enhanced to meet the needs and expectations of students' growth and development". We should not only integrate the "ideological and political" elements into the public courses such as Marxist principles, but also skillfully integrate them into the teaching process of various professional courses. It is also necessary for the management and various agencies to work together to improve the "curriculum ideological and political" work. The efficiency of education is to guide teachers and students to establish correct values, world outlook, and values, and to "build morality and foster people" as the fundamental task of education.
\end{abstract}

\section{Keywords}

Curriculum Ideology, High Quality, Course Thinking and Politics,

Lide Shuren

\section{Introduction}

$\mathrm{Xi}$, general secretary of the national ideological and political work conference, pointed out that "We must use the classroom teaching the main channel, ideological and political theory class to strengthen in improvement, improve ideological and political education affinity and pertinence, meet the needs of students' growth and expectations, other courses should keep a canal, good respon- 
sibility, make all kinds of courses and ideological and political theory class, form a synergistic effect", from now on, the concept of "curriculum" began to enter the public field of view (People's Daily, 2018a). In 2014, Shanghai issued the Shanghai Comprehensive Education Reform Plan (2014-2020), incorporated moral education into the comprehensive education reform, issued the special plan for the construction of curriculum ideological and political education and teaching system in Shanghai colleges and universities, put forward the concept of "curriculum ideological and political" and selected a number of pilot schools to promote it. Shanghai colleges and universities have begun a journey of ideological and political exploration from traditional to modern courses, and other regions have also paid great attention to the ideological and political courses.

In 2020, the Ministry of Education issued the guiding outline for ideological and political construction of institutions of higher education and clearly pointed out the ideological and political construction of colleges and universities: "We should integrate ideological and political education through the talent training system, comprehensively promote the ideological and political construction of college courses, give full play to the educational role of each course, and improve the quality of talent training in colleges and universities". The promulgation of this program has guided the direction for the development of ideological and political courses in the new era. We should not only integrate "ideological and political" elements into public courses such as Marxist principles, but also skillfully integrate them into the teaching process of each professional course. Management also needs to work together with various departments to improve the efficiency of "course ideological and political" work. Guide teachers and students to establish correct values, world outlook, and take "cultivating people by virtue" as the fundamental task of education.

\section{Curriculum Ideological and Political Concepts}

"Curriculum thinking and politics" is a new strategy of college education in the new era, and a new kind of curriculum view. To be specific, it is to naturally integrate ideological and political education content into the curriculum teaching system of professional courses. By digging the ideological and political elements in professional courses, students can receive positive value guidance while obtaining professional promotion, so as to realize the combination of knowledge teaching and ideological and political education. With full education, full education, comprehensive education as the pattern of "ideological" under the "course" ideological, requirements to moral education as the goal, curriculum as the gripper, pay attention to the course carrying ideological and political, ideological politics in curriculum, by giving full play to general knowledge, basic class, professional courses, practice courses and other kinds of moral education function, expand the time and space of ideological and political education, and realize from simple "political course" plane teaching to diversified "curriculum" three-dimensional teaching mode (Gao, 2021). 
"Curriculum ideological and political education" is not only an ideological and political education concept, but also an ideological and political education method. It is a kind of ideological and political education concept, refers to the "curriculum ideological and political education" is the rational understanding of ideological and political education in colleges and universities, ideal pursuit and formed concept system, is to understand and implement it from the perspective of curriculum implementation (He, 2019).

The essence of curriculum ideological and political education is curriculum moral education, which emphasizes the value attribute of curriculum and aims to lead education to return to its true nature. Therefore, it must give full play to the role of classroom teaching as the main channel of teaching education to form the ideological and political curriculum and the CPPCC.

"Curriculum ideological and political" and "ideological and political curriculum" can only create conditions for "going together", so as to realize the synergy effect (Qiu, 2018).

\section{Cultivate the Talents Needed in the New Era}

\subsection{Cultivating People by Virtue Is the Fundamental Task of Higher Education in the New Era}

In May 2018, Comrade Xi Jinping further clearly put forward the requirements of "patriotic, inspirational, truth-seeking and practical practice" for the young people (Wang, 2014). In September 2018, Xi Jinping stressed at the National Education Conference that he should adhere to the socialist education development path with Chinese characteristics and "train socialist builders and successors for all-round development of morality, intelligence, body, beauty, beauty and labor" (People's Daily, 2018b).

Comprehensively promoting the ideological administration of the curriculum is an effective way to promote the cultivation by virtue. Promote the ideological and political work in all aspects, infiltrate the thought of cultivating people by virtue, and guide students to establish correct values. We will implement the fundamental task of cultivating people through virtue and cultivate talents in the new era needed by society.

Due to the development and changes in the new era, universities transform from a traditional teaching center to a teaching and scientific research center, which poses new challenges to management. In terms of school management, we should focus on cultivating the talents needed in the new era, and the training of teachers should also be in line with the development trend of The Times and become the new blood of the university.

\subsection{Current Status of Ideological and Political Development}

The current ideological field facing ideological diversification, value pursuit of desire, public opinion network, social trend aggregation, western theory implantation and classroom discipline lax complex situation, guide contemporary college 
students to set up the correct values task has a long way to go, just rely on marque principle and other public class teacher difficult for this task, full-time teachers to be ideological and political elements into the relevant professional teaching content, expand its influence (Zhang, 2020). When imparting professional course knowledge, they skillfully integrate the "ideological and political" thought into it, so that the students can accept the thought of "ideological and political" imperceptibly.

Major is an important carrier for the ideological and political implementation of the curriculum. Each discipline can carry out "ideological and political" education from different perspectives according to their own characteristics. Teachers can write about it when writing the teaching plan, which has a stronger purpose and a better effect.

To integrate ideological and political elements into the teaching content, professional teachers need to have certain Marxist theoretical knowledge. Teachers need to skillfully integrate ideological and political elements into the teaching content in the process of teaching knowledge. In most cases, teachers lack the reserve of knowledge related to Marxist thought, and can not skillfully pass on ideological and political elements. The way of transmission is too rigid and the effect is not good, but completing the task violates the original intention of ideological and political affairs of the course.

\subsection{The Formation of a High-Level Talent Training System Is the Concrete Ideological and Political Work to Comprehensively Improve the Talent Training Ability Is the Fundamental Driving Force for the Talent Training in Higher Education in the New Era}

Comrade Xi Jinping pointed out: “To run China's universities well and run a world-class university, we must firmly focus on the comprehensive improvement of talent training, the core point of maintenance ability". Teaching management innovation is an important part of educational innovation, it is the management innovation and environmental system reengineering with the goal of high-quality undergraduate talent training, aiming to create a more perfect management concept, management system and mechanism, management platform for undergraduate talent training. In the new era, students should pay attention to inspire students of their own potential and cultivate students' innovative spirit (He, 2019). According to the different characteristics of the discipline, students are encouraged to participate in science and technology innovation competitions to promote learning through competition. Encourage students to participate in more social practice, carry out linkage and cooperation with enterprises, practice the true knowledge, through practice can better transform the knowledge learned.

Khalid id is the fundamental task of the new era of higher education, comprehensively improve the ability is the core link of the new era of higher education talent training work, ideological and political work is the new era of higher edu- 
cation talent training work, strengthen the leadership of the party and the grassroots organization construction in colleges and universities is the political guarantee of higher education personnel training work (Sun, 2019).

Integrating the ideological and political curriculum into the teaching content in a scientific and reasonable way will not only make the teaching content become boring, but will make the teaching content more colorful and silent way, deepen the depth of teaching, and stimulate students' initiative to master knowledge. Teachers should combine the characteristics of their own subjects, explore the depth of the teaching content, and actively penetrate the ideological and political elements. In the process of formulating the teaching plan, study the textbook carefully, grasp the initiative of the ideological and political affairs of the course, and organically combine the ideological and political elements with the professional course content.

\subsection{High-Quality Development of the Curriculum Ideological and Political Way}

Building a high team of quality teachers is a key link to comprehensively improve talent training ability.

Rejuvenating the country must be teachers first. Teachers are the first resource for education development. General Secretary Xi Jinping replied to the representatives of Huang Danian teachers in colleges and universities that good teachers should be teachers and behave, truly unify learning, things and people, and be a good guide for the growth of students.

Teachers' work in the front line of education work, is an important role in transmitting ideological and political thought. Ideological and political training for teachers is a very important task. The school should strengthen the importance of "curriculum ideological and political affairs" from the leadership and strengthen its publicity. For many teachers, "curriculum ideological and political affairs" is still a very vague concept. Even some teachers have misunderstanding of curriculum ideological and political concept, and need to do more publicity to strengthen their understanding of it. By carrying out lectures, publicity demonstration, communication and other ways, people are familiar with the ideological and political courses, thinking about better publicity on the basis of understanding, passing on to the majority of students, and gradually become teachers who love to speak "ideological and political".

The school strengthens the management from the institutional level, and urges the teachers to carry out the work of "curriculum ideological and political affairs". Gradually refine the evaluation indicators, refine the work, and improve the work effect. Under the guidance of the school, the college combines its own characteristics to refine the guidelines and urge the progress of the work of the secondary college. The full-time teachers do not forget to integrate the "ideological and political" elements into the classroom while improving the teaching quality, and skillfully combine the two together. The college regularly carries out ex- 
change meetings between full-time teachers, learn from each other, and set up a reward mechanism, so that teachers can gradually like "thinking and politics" in the classroom, and constantly innovate in ways and methods.

In terms of teaching methods, mixed teaching can try innovative teaching methods integrating various teaching methods, and the teaching process reflects the way of student-centered teaching and teachers' guidance. It is no longer the traditional cramming and indoctrination teaching, pay attention to mobilize students' subjective initiative, guide students to think actively, love to solve problems. During the process of teaching, appropriate interactive work was carried out to attract students attention through random selection, and to cultivate students' teamwork spirit through group discussion. Through flexible ways to let students actively accept ideological and political education.

We attach importance to the role of head teachers and counselors in the transmission process of "curriculum ideological and political affairs". This group has the most contact with students and the highest evaluation rate of dealing with students. We attaches attention to guiding students to establish correct values in work, and become college students with the comprehensive development of morality, intelligence, body, beauty and labor needed in the new era.

\section{Full-Time Teachers Can Explore the Ideological and Political Methods of High-Quality Development Courses in the Following Stages}

\subsection{The Initial Stage Is to Set Goals}

Formulate the general goal needs to start from the national principles and policies combined with the development characteristics of the school itself, adhere to the leadership of the party, establish the correct values, around the fundamental task of "cultivating people by moral education", refine the specific indicators, including: talent training objectives, curriculum construction objectives, teacher training objectives and so on.

Full-time teachers should pay attention to strengthening the teaching design link. The ideological and political course requires teachers to have a comprehensive understanding of students, including not only learning ability, learning attitude, interests and hobbies, but also ideological and political outlook, world outlook, outlook on life and so on. Knowing friends and the enemy helps teachers to better guide students to establish correct values in the teaching process. The teaching design link needs to constantly explore the actual situation of students. On the one hand, teachers need to constantly think and deliberate repeatedly, and on the other hand, they need to invite experts and scholars to comment on them and give advice.

\subsection{Mid-Term Method Implementation Link}

The class will integrate ideological and political elements into the content of the class, virtually impart ideological and political thoughts, and guide students to 
establish correct values and outlook on life. We will advocate prosperity, democracy, civilization and harmony, freedom, equality, fairness and rule of law, patriotism, dedication, integrity and friendliness, and actively cultivate and practice core socialist values. The school creates an atmosphere of "curriculum ideological and political" from the perspective of the general environment, enhances the awareness of "ideological and political" of teachers and students through regular seminars and other ways, and increases the "ideological and political" knowledge reserve of teachers and students through regular in-school training activities.

In the process of teaching, pay attention to teaching methods and enhance the teaching control ability, and use what way to better stimulate students' interest is what teachers need to pay attention to. Use heuristic and exploratory teaching methods to guide students to think and explore. In the era of developed network technology, the use of multimedia equipment and mixed online and offline teaching can better improve the learning effect.

Course ideological is a kind of teaching innovation, professional teachers is an important task is to combine professional course content and ideological elements, teach ideological and political thought reflect the characteristics of professional knowledge, the traditional Confucian culture, philosophical spirit and the new era of socialist core values, retain the innovative spirit of traditional thought and the characteristics of the new era. Through the clever infiltration of ideological and political elements into the content of professional courses, students can learn the knowledge of professional courses while the ideological realm is sublimated, and establish a correct world outlook, outlook on life and values to become good young people in the new era. Can achieve the unity of knowledge and action, what you have learned to use.

In addition to innovative teaching methods, you can also join the assessment link to understand the students' grasp of ideological and political knowledge, and mobilize the enthusiasm of students to learn ideological and political thought. Pay attention to students' learning attitude, emotions and values, through some case analysis questions or let students write small papers to assess, and encourage students to actively participate in associations and other social practice activities. Combine the online and offline evaluation methods to master the students' learning situation.

\subsection{Later Stage Is the Evaluation and Exchange}

The important task of ideological and political courses is to cultivate students to establish the correct values, world outlook and outlook on life in the new socialist era, and the implementation effect is crucial. Need to evaluate whether it works good. The implementation effect of the course is difficult to measure specifically.

Regular communication activities, including student feedback, are needed. As a direct audience, students' feedback is of great significance for teachers to adjust the teaching plan, and to ensure that there is a reasonable platform for dialogue 
and communication between teachers and students. Set reasonable of curriculum knowledge, learning ability, learning ability and other aspects of the goals. Replace the old knowledge, the inappropriate teaching methods, and keep the advanced teaching methods and the teaching content novel. Combining the characteristics of this major should be combined to integrate the knowledge of industry, education and research collaborative education to stimulate students' interest and creativity. Regularly carry out exchange activities such as demonstration classes, invite famous experts and scholars in the industry to comment, and pay attention to the opinions of peers and students. Continue to carry out teaching reflection, adjust the teaching plan and teaching methods, improve the teaching effect.

\subsection{Finally, the Sorting and Optimization}

Overall do the design of the course according to the characteristics of the course, give full play to the educational function of each course. In the process of imparting knowledge, teachers should combine the characteristics of this course, appropriately expand the knowledge surface, integrate into the current political hot spots and other information, and expand the students' knowledge while imperceptibly achieving the classroom "ideological and political". It also needs to use the teaching tools and platforms in the new era, and use multimedia equipment to choose the way that students want to adapt to teaching, so as to improve the rise rate and the absorption effect of students. Have the courage to innovate in the teaching methods and tools, keep pace with The Times, and constantly innovate.

\subsubsection{Set up a Scientific and Reasonable Evaluation Mechanism}

Schools can incorporate the effect of teachers' ideological and political implementation of the curriculum into the assessment mechanism, and set up scientific and reasonable evaluation indicators to evaluate them. It can be carried out through student feedback, peer mutual evaluation and supervision expert evaluation, summarize scientific and reasonable comprehensive score values, and teachers can self-adjust the teaching plan and teaching methods according to the feedback, so as to improve the teaching effect of ideological and political administration of the course.

\subsubsection{Collaborative Education Mechanism}

For colleges and universities, carrying out curriculum ideological and political work is the task of the team, not the work of a single teacher and a certain college. All parties cooperate to carry out the ideological and political work of the course, which is the most important effect.

The various colleges of the school and between the various departments are not independent individuals, and they need the close cooperation of the various departments in the transmission of "curriculum thinking and administration". The department coordination requires the ideological and political synergy of 
the curriculum through the leadership of the Party committee, the guidance of disciplines and majors, the implementation of academic departments, theoretical support from Marxist College, the participation of students by academic departments, the effective implementation of professional teachers, and student feedback experience $(\mathrm{Qu}, 2019)$.

The first is the mutual collaboration between full-time teachers and ideological and theory class teachers. Ideological and political theory courses and professional courses, ideological and politics, are closely connected between the two, with both differences and connections. Ideological and politics is actually an extension and extension of the general thought in the ideological and political theory class. For professional teachers, they need to have a certain knowledge reserve of ideological and political theory, and it is not enough to only master the general theory and simple basic content. They need systematic training to deepen their own knowledge reserve. Only after mastering the understanding, we can naturally and flexibly penetrate in professional classes. Each discipline has its own characteristics, from history, humanities, news and other aspects to penetrate. Ideological and political class teachers can penetrate the latest knowledge points in the field by carrying out regular training or lectures, and carry out regular dialogue and exchanges with full-time teachers to ensure that the ideological and political knowledge reserve of full-time teachers has timeliness. Ideological and political theory courses also need the expansion and penetration of professional courses.

In the whole course of ideological and political work, ideological and political teachers play the role of supporters, and professional teachers is cooperation, embodied in the teaching activity design, teaching activities (process monitoring, method, evaluation), such as cooperation, not only conducive to professional course ideological and political activities, but also can enrich the ideological and political theory teaching method system.

\section{Conclusion}

Classroom thinking and politics have become a new trend of university education reform, and it has become a trend to gather all forces of the whole school to carry out moral education. The aim is to cultivate students to learn professional courses and at the same time guide students to establish correct values, outlook on life and the world. The new era for college students requires them to be able to apply what they have learned and actively understand ideological and political thought.

\section{Conflicts of Interest}

The authors declare no conflicts of interest regarding the publication of this paper.

\section{References}

Gao, S. (2021). Exploration and Practice Graduate Education of Graduate "Curriculum Ideological and Politics" under the Pattern of "Great Thinking and Politics". Graduate 
Education Research, 5, 70-75.

He, Y. H. (2019). Exploration of Ideological and Theoretical Education Guide on the Essential Connotation and Realization Path of "Curriculum Ideological and Politics". Journal of Ideological and Theoretical Education, 10, 130-134.

People's Daily (2018a). Speech at the Teachers and Student Forum at Peking University.

People's Daily (2018b). Stressed the Path of Socialist Education Development with Chinese Characteristics to Cultivate Morality, Intelligence, Sports and Beauty Lowe's AllRounded Socialist Builders and Successors.

Qiu, R. F. (2018). Theoretical Interpretation of "Curriculum Ideological and Political" and "Ideological and Political Course" in the Same Direction Ideological Education Research. Ideological Education Research, 4, 109-113.

Qu, L. Y. (2019). Knowledge of Talent Training in the Higher Education Teaching in the New Era. Chinese University Teaching, 1, 7-12.

Sun, Y. H. (2019). Innovates the Teaching Management to Promote the Ideological and Political Reform of College Courses and Explore the Teaching of Chinese Universities. Chinese University Teaching, 5, 55-59.

Wang, J. N. (2014). Grasp the Complexity and Initiative of College Ideological Work. Research on Ideological Education, 10, 53-56.

Zhang, H. (2020). University Curriculum about the Dilemma, Elements and Path of CPPCC Education Effect of National School of Education Administration. Journal of the National Academy of Educational Administration, 10, 31-36. 